\title{
WYCHOWANIE NA LEKCJACH PRZEDMIOTÓW PRZYRODNICZYCH I TECHNIKI
}

\begin{abstract}
Abstrakt: W kanonie edukacji od zawsze było miejsce na uczenie przyrody. Przedmiot ten służy nam jako narzędzie do opisywania wszechświata jak również roli i miejsca człowieka w świecie. Zgłębianie tej wiedzy zaspokaja naturalną ciekawość człowieka dotyczącą otaczającego go świata. W dzisiejszych czasach przyrodoznawstwo i nauki techniczne dążą nie tylko do przekazania uczniom podstawowej wiedzy. Ich zadaniem jest również osiągnięcie różnych celów dydaktycznych, takich jak: rozwijanie pożądanych postaw, zainteresowań, cech charakteru, poczucia odpowiedzialności i wpajanie określonych wartości. Jedynie dobór odpowiednich metod nauczania, które umożliwiają uczniom aktywne zaangażowanie się w rozwiązywanie problemów edukacyjnych, podejmowanie indywidualnej inicjatywy, zgłębianie przedmiotu, dostrzeganie wartości pracy oraz docenianie osiągnięć naukowych, może przyczynić się do pełnego obrazu wartości edukacyjnych, ich zrozumienia i przyswojenia. Poznanie historii nauk przyrodniczych, techniki oraz biografii naukowców i wynalazców powinno skłonić uczniów do głębszej refleksji na temat roli człowieka w powiększeniu i udoskonaleniu historycznych osiągnięć kultury i cywilizacji, znaczenia poświęcenia, pasji i nieustępliwości w dążeniu do celu.
\end{abstract}

Słowa kluczowe: nauczanie przyrody i techniki, metoda projektów, wartości, wychowanie

\section{WPROWADZENIE}

W społecznej ocenie szkoła nadal pozostaje najważniejszą instytucją odpowiedzialną za przekaz wartości i wspomaganie rozwoju akceptowanych powszechnie postaw wobec zadań i wyzwań wynikających z rozwoju kultury i cywilizacji. Mimo tego, iż skutki jej działalności poddawane są niejednokrotnie miażdżącej krytyce, większość Polaków uważa, że należy i warto się kształcić (Wciórka 2009). 
Wiara w sprawcze możliwości edukacji szkolnej skłania do podejmowania ustawicznych prób reformowania systemu szkolnego, jego programów nauczania, organizacji i zarządzania obejmującego nadzór pedagogiczny, finansowanie, motywowanie nauczycieli.

Wśród prób wyjaśnienia powodów niezadowalającej funkcjonalności szkoły często wskazuje się na główną przyczynę, jaką jest jej chroniczne niedoinwestowanie - niskie wynagrodzenia nauczycieli, brak środków na utrzymanie małych szkół, do których uczęszcza niewielu uczniów, likwidację tzw. zajęć pozalekcyjnych (Herbst, Herczyński, Levitas 2009). Nie podważając zasadności i trafności temu podobnych opinii, warto jednak rozważyć to, jakie działania w dziedzinie doboru i realizacji treści nauczania poszczególnych przedmiotów pomogłyby uczynić kształcenie i wychowanie bardziej efektywnym i skutecznym, poprawić jakość edukacji na wszystkich szczeblach. Powszechnie wiadomo, że o jej rezultatach w decydującym stopniu przesądzają nie tyle warunki materialne, co osobiste zaangażowanie w proces dydaktyczno-wychowawczy zarówno nauczycieli, jak i samych uczniów (Błażejewski 2011).

Uczeń aktywny - zainteresowany, pracowity, odpowiedzialny, refleksyjny, pozytywnie zmotywowany do zgłębiania wiedzy, pracując pod kierunkiem kompetentnego nauczyciela, ma realne szanse na osiągnięcie sukcesów szkolnych, zawodowych i społecznych. Brak stosownej motywacji do podejmowania wysiłku uczenia się - pracy nad własnym wszechstronnym rozwojem intelektualnym, moralnym, fizycznym, przekreśla wszelkie starania nauczycieli, nadzoru pedagogicznego, władz samorządowych, zmierzające do poprawy funkcjonalności szkolnictwa. Nasuwają się więc pytania: Jak motywować dzieci i młodzież do uczenia się - niejednokrotnie trudnych przedmiotów, do których często zalicza się matematykę, fizykę, chemię, niektóre przedmioty zawodowe? W jaki sposób przekonać większość uczniów do znaczenia i walorów wiedzy przyrodniczej oraz technicznej, a także do potrzeby, obowiązku i sensu jej zgłębiania?

Rozwijanie określonych postaw rozumianych jako stosunek do wybranych zadań i obowiązków - tu uczenia się określonych w programie kształcenia przedmiotów - stanowi złożone wyzwanie wychowawcze, które, jak wskazują liczne przykłady z praktyki szkolnej, sprawia wielu nauczycielom istotne trudności. Nie potrafią oni np. zaprezentować swoim uczniom treści nauczanego przez siebie przedmiotu szkolnego w sposób, który wzbudzałby ich zaciekawienie, fascynację, potrzebę głębszego poznania, chęć doskonalenia własnych umiejętności w wybranej dziedzinie, włączenie się w dalsze pomnażanie dotychczasowego dorobku naukowego. 


\section{WYCHOWAWCZE WALORY POZNAWANIA BIOGRAFII UCZONYCH I WYNALAZCÓW}

Od zarania dziejów człowiek stawiał pytania dotyczące zjawisk przyrodniczych, praw nimi rządzących, swojej natury i miejsca w systemie wszechświata, dążąc do zaspokojenia wrodzonej mu ciekawości i potrzeby poznania. Doprowadziły one do powstania i rozwoju początkowo filozofii przyrody (Archimedes, Demokryt $\mathrm{i}$ in.), a następnie stopniowo dyscyplin naukowych - matematyki, fizyki, chemii).

Rozpoczęcie systematycznego nauczania przedmiotów przyrodniczych wymaga stosownego przygotowania uczniów - pracy wychowawczej - wyjaśnienia im sensu podejmowanego trudu, poświęcenia czasu i energii na naukę określonych definicji, twierdzeń wzorów, praw. Współcześni uczniowie często nie znają historii rozwoju nauki i techniki, nie potrafią docenić znaczenia wielu odkryć i wynalazków, dzięki którym cywilizacja osiągnęła dzisiejszy, wysoki poziom. Nie mają świadomości tego, jak ogromnego wysiłku wielu pokoleń uczonych potrzeba było, aby dzisiaj można było powszechnie korzystać np. ze skutecznych leków, zabiegów medycznych, urządzeń telekomunikacyjnych i transportowych, wydajnych technologii produkcji dóbr konsumpcyjnych.

Wielu gimnazjalistów korzystających na co dzień z telefonu komórkowego, np. do łączenia się z Internetem, przesyłania wiadomości tekstowych, głosowych, robienia zdjęć i filmów, nie potrafi chociażby ogólnie opisać zasady jego działania - podać treści elementarnych praw fizyki, których poznanie umożliwiło jego skonstruowanie. Na lekcjach uczniowie niewiele dowiadują się o tym, w jaki sposób człowiek poznawał świat przyrody, jakie ponosił koszty tego poznania, co zawdzięczamy tym, którzy poświęcali zdrowie, czas i majątek na to, by poznać i zrozumieć przyrodę, a swoją wiedzę upowszechnić w społeczeństwie po to, by poprawić jakość jego życia, a także zaspokoić własne ambicje oraz realizować marzenia.

Poznawanie biografii wybitnych polskich i światowych uczonych i wynalazców pozwala patrzeć na świat oczami pasjonatów, poznawać nowe wartości i wzorce postępowania, niejednokrotnie skłania do głębszych refleksji nad miejscem i rolą człowieka w przyrodzie, inspiruje do poszukiwania i rozwijania własnych trwałych zainteresowań. Dostarcza wiedzy o trudnościach, na jakie napotykali badacze praw natury, co pozwala na lepsze zrozumienie wartości ich osiągnięć i znaczenia wykonanej na rzecz społeczeństwa pracy. Umożliwia też poznanie wzorców osobowych, orientacji życiowych, aspiracji, celów, modeli samorealizacji, hierarchii wartości. Dostarcza przykładów wytrwałości, systematyczności, pracowitości i ofiarności w dążeniu do nadania własnemu życiu głębszego sensu przez aktywne uczestnictwo w kulturze - pomnażanie jej dorobku. 
W czasach narastającego konsumeryzmu, powszechności, a nawet dominacji postaw roszczeniowych i hedonistycznych u młodych ludzi, warto ukazywać im odmienne wzory postępowania i wyborów życiowych. Dążąc do rozwijania pozytywnych postaw, trzeba przede wszystkim dostarczać odpowiedniej wiedzy o ludziach, którzy zyskali powszechne, trwałe uznanie za to, jak na co dzień żyli i co osiągnęli. Nie można czegoś polubić, uczynić celem swoich dążeń, bez uprzedniego dokładnego poznania. Prezentowanie biografii uczonych, analiza ich twórczości, ocena zasług, a także popełnianych błędów i ich przyczyn, z racji głębokich walorów wychowawczych nie mogą być marginalizowane lub pomijane, jak ma to często miejsce w obecnej edukacji przyrodniczo-technicznej, zwłaszcza w początkowym okresie nauki. Można postawić tezę, że rozwój zainteresowania określoną postacią warunkuje też zainteresowanie się tym, czego, jak i dlaczego ona dokonała.

W czasach, gdy dostęp do rozmaitych źródeł wartościowych informacji jest powszechny i łatwy, przygotowanie odpowiednich dla uczniów materiałów - atrakcyjnych w formie, zrozumiałych i zwięzłych - nie powinno sprawiać żadnemu nauczycielowi kłopotów. Podobnie jak wybór trafnych metod nauczania, z których do realizacji obranych celów wychowawczych doskonale nadają się np. pogadanka, dyskusja (po filmie czy lekturze), burza mózgów i inne. Bogatą ofertę filmów o charakterze dokumentalnym i fabularyzowanych, poświęconych historii epokowych naukowych odkryć i wynalazków na całym świecie, znaleźć można na wielu kanałach telewizyjnych, np. National Geographic, Discovery Channel, Discovery Science.

Wzbudzenie pozytywnej motywacji do podjęcia trudu systematycznego uczenia się rozmaitych zagadnień wymaga przekonania uczniów do celowości podejmowanego wysiłku - ukazania im możliwości spożytkowania zdobywanej wiedzy w praktyce, osiągania satysfakcji i różnorodnych wymiernych korzyści. Niezbędne do tego jest tworzenie warunków, w których można by realizować wspólnie interesujące, ambitne zadania - podejmować np. prace badawcze, racjonalizatorskie, koncepcyjne na rzecz środowiska lokalnego. Wielokrotnie dowiedziono, że uczniowie pracujący i współpracujący ze sobą w zespołach zadaniowych rozwijają skutecznie swoje kompetencje społeczne, umiejętności rozwiązywania nietypowych problemów, poszukiwania wiedzy, wdrażają się do dyscypliny, odpowiedzialności, samokontroli. Praca w grupach problemowych sprzyja także wzmacnianiu więzi międzyludzkich, wzajemnemu poznaniu swoich zdolności, potrzeb i możliwości, poczuciu przynależności. Dopinguje do dbałości o wysoką pozycję społeczną, dobrą opinię, szacunek, zaufanie wśród uczestników. Pozwala konfrontować własne poglądy z opiniami i ocenami innych osób (Nowacki 1999). 


\section{WYKORZYSTANIE METODY PROJEKTÓW UCZNIOWSKICH W WYCHOWANIU}

Warunki korzystne do rozwoju wielu istotnych cech charakteru i postaw stwarzają nauczyciele wykorzystujący w pracy dydaktyczno-wychowawczej metodę projektów uczniowskich, która mimo oczywistych zalet nie należy jednak do powszechnie stosowanych w kształceniu przyrodniczo-technicznym w szkołach ogólnokształcących. Ograniczenie czasu zajęć w pracowniach i laboratoriach szkolnych sprawia, że na lekcjach prowadzonych metodą wykładu przekazywana jest głównie gotowa, uporządkowana wiedza, którą należy zapamiętać, by z czasem można było wykazać się jej znajomością podczas sprawdzianu czy egzaminu. Taka sytuacja nie sprzyja rozwijaniu zainteresowania przedmiotem nauczania, emocjonalnemu zaangażowaniu się w proces nauczania-uczenia się, a przez to też trwałości i operatywności nabywanej wiedzy, uzyskiwaniu satysfakcjonującej efektywności i skuteczności kształcenia.

Szczególne walory kształcące i wychowawcze mają uczniowskie projekty o charakterze badawczym, w których mogą brać czynny udział dzieci i młodzież z wielu szkół na terenie kraju czy Europy, dotyczące np. zagadnień związanych z ochroną środowiska naturalnego człowieka, zmian klimatycznych, niekonwencjonalnych źródeł energii, migracji zwierząt i wielu innych. Sprzyjają one rozwojowi umiejętności nawiązywania wzajemnych kontaktów, współpracy, wymianie doświadczeń i poznawaniu różnych kultur, umacnianiu ogólnoludzkiej solidarności w dążeniach do pokonywania istotnych współczesnych problemów. Przykładami wzorcowo przeprowadzonych międzynarodowych projektów ekologicznych, w których wzięły udział setki szkół europejskich, w tym także polskich, były kampania ozonowa i badanie zanieczyszczeń powietrza wywołującego opady kwaśnych deszczy w latach dziewięćdziesiątych XX wieku. W ramach tych projektów istniała możliwość dokonywania również szerokiej wymiany kulturalnej, tworzenia tzw. klas bliźniaczych pochodzących z różnych państw i biorących udział w tym przedsięwzięciu (Krogulecka 1994).

Współczesne możliwości komunikacyjne, jakie stwarza Internet, ułatwiają nawiązywanie współpracy międzyszkolnej, poszukiwanie partnerów i tematów do wielu wspólnych projektów, rozwiązywania wspólnych problemów w ramach edukacji przyrodniczej i technicznej. Realizacja projektów wymaga jednakże od nauczycieli pomysłowości, dużego nakładu pracy organizacyjnej, koncepcyjnej, a przede wszystkim pogodzenia potrzeb edukacyjnych wynikających ze specyfiki planowanych zadań z wymogami podstawy programowej i zasadami oceniania uczniów, które zdaniem wielu uniemożliwiają stosowanie na szerszą skalę takich atrakcyjnych dla uczniów rozwiązań metodycznych. Jednym z trudnych wyzwań 
edukacji jest przygotowanie kolejnych pokoleń do życia w warunkach narastania nierozwiązanych dotąd ogólnoludzkich problemów, takich jak kurczenie się zasobów surowców naturalnych, epidemie nieuleczalnych chorób, groźne zmiany klimatyczne wywołujące kataklizmy, skażenie i zanieczyszczenie zasobów wody pitnej, głód, pustynnienie obszarów rolniczych, przeludnienie. Podejmowanie prób ich rozwiązywania wymaga posiadania gruntownej, wszechstronnej wiedzy oraz wrażliwości i poczucia odpowiedzialności za przyszłe losy ludzkości i cywilizacji. Odpowiedzialne działania podejmowane są wówczas, gdy kierujemy się poznanymi i akceptowanymi wartościami etycznymi - dobrem powszechnym, sprawiedliwością, poszanowaniem wszelkich form życia, godnością i mądrością. Człowiek wykształcony, dysponujący coraz potężniejszymi środkami technicznymi, ale pozbawiony zasad moralnych, nieświadomy konieczności ich respektowania w każdej dziedzinie życia, eksploatujący zasoby naturalne planety w sposób rabunkowy, nieprzemyślany, nie jest jej „troskliwym gospodarzem”, lecz poważnym zagrożeniem.

Dynamika degradacji środowiska naturalnego skłania do refleksji nad sposobami jej zahamowania. Jako jeden $\mathrm{z}$ nich wskazywana jest powszechnie stosowana edukacja -dostarczenie niezbędnej wiedzy oraz wychowanie do racjonalnego, bezpiecznego gospodarowania kurczącymi się zasobami przyrody, dbałości o jej stan i odpowiedzialność. Wychowanie proekologiczne, prozdrowotne winno zatem stanowić nieodłączny element edukacji przyrodniczo-technicznej. Technika nie może na dłuższą metę stanowić coraz powszechniejszego zagrożenia dla podstaw egzystencji przyszłych pokoleń, a wprost przeciwnie - umożliwiać coraz łatwiejsze i bezpieczniejsze życie.

Odpowiedzialne myślenie o przyszłości całej ludzkości nakazuje powszechne uświadamianie uczniom już na etapie szkoły podstawowej i gimnazjum tego, że rozwój i bogacenie się państw wysoko rozwiniętych odbywa się kosztem degradacji środowiska, związanej z pozyskiwaniem surowców energetycznych, rud metali, materiałów budowlanych - kamienia, drewna - w państwach trzeciego świata, gdzie coraz szersze kręgi ludności skazane są przez to na życie w nędzy i wysoką śmiertelność. „Ten sam przemysł, który liczydło zastąpił kalkulatorem, rumaka automobilem, kotlet hamburgerem etc. - wybił «dziurę ozonową» nad głowami ludzi, eksterminował wielkie połacie przyrody, i kontynuuje wszystkie te zbrodnie, dręcząc tudzież zaśmiecając planetę bez ustanku. Ten sam ludzki geniusz, który teorią względności czy teorią kwantów wydatnie rozszerzył wiedzę człowieka - rozbił atom dla Hiroszimy, Nagasaki, Czarnobyla i wiecznego strachu przed bombą termojądrową. Nowoczesne (mechaniczne, chemiczne, biologiczne) środki masowego mordu są ceną za lodówkę, telewizję i helikoptery. Cudowne dziecko naukowego postępu - pigułka antykoncepcyjna - upowszechniła (udemokratyczniła) żywiołową seksualność (niestałość) kobiet, rujnując tradycyjna rodzinę" (Łysiak 2000, s. 13). 
Uwrażliwianie na zagrożenia, specyficzne potrzeby w dziedzinie ochrony środowiska naturalnego powinno zaowocować podejmowaniem rozmaitych inicjatyw dotyczących lokalnych działań na rzecz ograniczania ilości zużywanej energii, wytwarzanych zanieczyszczeń, odpadów, ochrony fauny i flory.

Ochrona lokalnego środowiska naturalnego może stanowić atrakcyjny temat uczniowskich projektów, prac badawczych, konkursów wiedzy i inicjatyw. To przygotowanie do rozwijania postaw twórczych, które cechuje m.in. odwaga w podejmowaniu decyzji, zaufanie do własnych umiejętności, chęć odkrywania nowych dróg dochodzenia do ambitnych celów, oryginalność myślenia. W obecnym modelu organizacyjno-treściowym kształcenia przyrodniczego preferuje się przekazywanie gotowych wzorów rozwiązywania typowych zadań, reprodukowanie przez uczniów wiadomości wybranych przez nauczyciela i przyjętych za ogólnie obowiązujące. W popularnych ocenach często spotkać można zarzut, że treści nauczania dotyczą jedynie sztucznie stwarzanych „szkolnych problemów” i pozostają oderwane od sytuacji występujących w codziennym życiu. Fakt ten może skutecznie zniechęcać do ich zgłębiania (Błażejewski 2011).

Rozwijanie postaw twórczych na lekcjach przedmiotów przyrodniczych jest możliwe, wymaga jednak starannego doboru problematyki i określenia zasad oceniania pracy uczniów, a także systematycznego ćwiczenia z nimi tego, jak wykraczać poza myślenie stereotypowe, konwencjonalne, schematyczne. Przygotowanie do twórczości naukowej i technicznej wymaga ćwiczenia umiejętności koncentracji uwagi, spostrzegawczości, logicznego myślenia. Z punktu widzenia efektów pracy twórczej ważne są nie tylko operatywność i wszechstronność nabytej wiedzy, ale odpowiednie cechy charakteru - dociekliwość, otwartość na zmiany, nonkonformistyczne nastawienie do życia.

Zapotrzebowanie na osoby twórcze, przedsiębiorcze i operatywne jest we współczesnym społeczeństwie coraz większe. Niezbędne są one w każdej dziedzinie - w nauce, polityce, przemyśle, gdyż to dzięki nim możliwy jest ustawiczny postęp i rozwój społeczeństwa. Ludzie twórczy muszą wykraczać poza utrwalone, zastane warunki, dostrzegać obszary warte poznania, projektować doskonalsze rozwiązania organizacyjne, techniczne w coraz bardziej komplikującej się sytuacji polityczno-gospodarczej na świecie. Zaletą podejmowania przez uczniów działań twórczych jest m.in. to, że poznają oni przy tym, jak wiele trudu, czasu, a niejednokrotnie także nakładów finansowych wymaga tworzenie dzieł techniki, sztuki, nauki. Podejmując próby własnej twórczości - wykonując projekty techniczne, projektując badania naukowe (oczywiście w miarę swoich możliwości) mają możność poznania i ocenienia wartości dzieł tworzonych przez innych ludzi. Uczeń, który zaprojektował i wykonał własny model latawca, lepiej i szybciej zrozumie, na czym polega wielkość dokonań konstruktorów szybowców, samolotów czy pojazdów 
kosmicznych. Redaktorzy szkolnych gazetek czy stron internetowych potrafią trafniej, pełniej ocenić profesjonalizm dziennikarzy i redaktorów radiowych czy telewizyjnych.

W stereotypowym traktowaniu przedmiotów nauczania zwykło się dzielić je na humanistyczne, przyrodnicze i ścisłe. Jest do podział tradycyjny, umowny i nieodpowiadający współczesnemu pojmowaniu istoty humanizmu, a przez to sugerujący zróżnicowane możliwości wykorzystania ich treści do realizacji zadań wychowawczych szkoły. Konsekwencją tego stanu jest ograniczanie pracy pedagogicznej na lekcjach przedmiotów przyrodniczych i ścisłych do działań dydaktycznych - przekazywania wiadomości, ćwiczenia praktycznych umiejętności, takich jak układanie planów rozwiązywania zadań, stosowania i przekształcania wzorów, przeliczania, obliczania, podstawiania danych, przeprowadzania dowodów twierdzeń, układania i rozwiązywania równań. Konieczność posługiwania się na lekcjach fizyki i chemii wiedzą z matematyki sprawia, że wielu uczniów uznaje te przedmioty za trudne, nudne, będące tzw. złem koniecznym.

Wyniki licznych badań naukowych dowodzą m.in., że zainteresowanie wiedzą przyrodniczą wśród dzieci przychodzących do klasy czwartej szkoły podstawowej jest bardzo duże, w kolejnych latach szybko jednak maleje, w miarę jak poznają one fizykę, chemię, biologię - oczywiście nie dotyczy to wszystkich, ale znacznego odsetka uczniów. Jak deklarują badani, treści tych przedmiotów rozczarowują, nie dają odpowiedzi na nurtujące ich pytania - często natury filozoficznej, egzystencjalnej - a naukowy język używany przez nauczycieli utrudnia zrozumienie sensu przekazu, prowadzi do zagubienia i bezradności intelektualnej. W rezultacie dochodzi do unikania tych lekcji, rozmaitych nagannych prób otrzymywania pozytywnej oceny, przyjęcia strategii „na przetrwanie” (Błasiak, Godlewska, Turkiewicz 1999).

\section{WYCHOWAWCZA ROLA PRACY}

Bogactwo treści przyrodniczych i technicznych, jakie przewidziano do realizacji w szkołach ogólnokształcących, pozwala na wykorzystywanie ich do osiągania wymiernych efektów wychowawczych - wzbudzania pozytywnej motywacji do nauki, rozwijania postaw proekologicznych i prozdrowotnych, twórczych. Służy także rozwijaniu zainteresowań, odkrywaniu zdolności, tworzeniu w umysłach uczniów naukowego obrazu otaczającego ich świata. Skłania też do refleksji nad dokonaniami wielu pokoleń uczonych, konstruktorów i wynalazców, dzięki którym kultura i cywilizacja osiągnęły obecny poziom. Umożliwia również zaprezentowanie znaczenia pracy ludzkiej rozumianej jako systematyczny i konsekwentny 
wysiłek fizyczny oraz intelektualny w przekształcaniu warunków życia człowieka, poznaniu tajemnic przyrody.

W czasach powszechnej komputeryzacji i automatyzacji wartość pracy umysłowej - koncepcyjnej, twórczej - ustawicznie wzrasta. Na rynku pracy zapotrzebowanie na ludzi dysponujących wiedzą będącą na wysokim poziomie specjalistyczną, charakteryzujących się pomysłowością, innowacyjnym myśleniem, kreatywnością ustawicznie wzrasta. Postęp technologiczny sprawia, że wiele prac można wykonywać kosztem mniejszego wysiłku mięśni, lecz większego wysiłku intelektualnego. Doskonałą okazją wdrażania się do pracy, w której trzeba wykorzystywać nabywaną w szkole wiedzę, wykazywać się pomysłowością i umiejętnościami organizacji i samokontroli własnych działań, są lekcje przedmiotów przyrodniczych prowadzone w pracowniach, gdzie uczniowie mogą przeprowadzać proste badania i eksperymenty naukowe. Zespołowe lub indywidualne zadania realizowane w pracowniach stanowić mogą namiastkę przyszłej pracy zawodowej. Wielu uczniów tak je właśnie traktuje, angażując się w nie emocjonalnie, co służy również rozwojowi i pogłębianiu określonych zainteresowań.

Prace badawcze, przeprowadzanie eksperymentów i prób w szkolnych pracowniach oraz laboratoriach powodują, że nauka jest bardziej urozmaicona, a przez to też chętniej podejmowana przez uczniów, co korzystnie wpływa na jej efektywność. Monotonny przekaz wiedzy, trwający kilka godzin dziennie, wywołuje znużenie, a czasem zniechęcenie i dekoncentrację - rozproszenie uwagi, wyłączanie się z zajęć. Uczniowie znużeni lub znudzeni często próbują na różne sposoby uatrakcyjnić sobie czas spędzany na lekcjach, co zwykle nie znajduje aprobaty u nauczycieli, prowadząc do konfliktów.

Do korzyści, jakie przynoszą lekcje przedmiotów przyrodniczych i technicznych prowadzone w pracowniach, należy także rozwój umiejętności gospodarowania przez uczniów czasem. Chcąc wykonać określone zadanie w wyznaczonym przez nauczyciela czasie, uczeń nie może sobie pozwolić na przystąpienie do niego bez uprzedniego gruntownego teoretycznego przygotowania, na zajmowanie się sprawami z nim niezwiązanymi, zbyt częste pomyłki, bałagan na stanowisku pracy, niedostatki we własnej wiedzy lub też oczekiwać na pomoc ze strony kolegów. To, że czas jest rzeczywiście istotną wartością, można poznać w pełni wtedy, gdy jego ilość na realizację ważnych przedsięwzięć jest ograniczona. Poszanowanie czasu własnego i cudzego świadczy o odpowiedzialności człowieka za los własny i losy innych ludzi, o jego kompetencjach społecznych. W dobie coraz szybszych zmian kulturowych, rosnącego tempa życia codziennego, ciągłego pośpiechu i pogoni za uciekającymi szansami, refleksja nad tym, jak umiejętnie dysponować czasem, warta jest upowszechniania i pogłębiania (Furmanek 2008). 


\section{WYCHOWANIE JAKO PRZEKAZYWANIE SZCZEGÓLNYCH WARTOŚCI}

Realizacja treści nauczania przedmiotów przyrodniczych umożliwia nauczycielom przekazywanie, a uczniom przeżywanie wielu wartości. Wartością szczególnie istotną jest życie, będące jak na razie fenomenem na skalę kosmiczną. Postawy ludzi wobec wszelkich form życia przesądzić mogą o jego dalszym istnieniu, o rozwoju bądź unicestwieniu człowieka, jego kultury i cywilizacji. Wyzwaniem dla współczesnej nauki jest poznanie tajemnicy życia, wytworzenie chociażby najprostszego żywego organizmu, nie mówiąc już o organizmie posiadającym inteligencję. Prostszym, bardziej realnym zadaniem jest poznanie mechanizmów jego powstawania i ochrony. Współcześnie, jak nigdy wcześniej, działalność człowieka powoduje masową zagładę całych gatunków zwierząt i roślin.

Przekonanie uczniów do potrzeby ochrony wielu form życia wymaga ukazania jego złożoności, doskonałości i piękna - tych cech, których człowiek mimo czynionych od wieków wysiłków nie jest, mimo potęgi swego umysłu, stworzyć. Fakt, że jest ono zjawiskiem wyjątkowym w dostępnym naszemu poznaniu Wszechświecie, powinien skłaniać do refleksji, podziwu i szacunku.

Poznając budowę, zasady funkcjonowania różnorodnych form żywych organizmów człowiek wielokrotnie wykorzystywał zdobytą wiedzę do projektowania i konstruowania urządzeń technicznych. Żywa przyroda stawała się inspiracją dla inżynierów i wynalazców, dostarczając im wzorców i pomysłów rozwiązywania szeregu problemów, związanych m.in. $z$ transportem $w$ różnych środowiskach. Jedną z negatywnych cech współczesnej cywilizacji jest brak poszanowania dla życia - nie tylko ludzkiego, ale również fauny i flory. Postępująca urbanizacja i eksploatacja zasobów bogactw naturalnych powoduje, że z roku na rok giną bezpowrotnie dziesiątki gatunków przyrodniczych - przybywa pustynniejących i skażonych, niesprzyjających życiu obszarów. Człowiek skutecznie niszczy w ciągu dziesięcioleci to, co przez miliardy lat ewolucji stworzyła przyroda, a czego sam nie jest w stanie wytworzyć (Łysiak 2000).

Dążąc do bezwzględnego zapanowania nad przyrodą, zaniedbuje często obowiązki gospodarza na swojej wyjątkowej planecie. Wyrazem szacunku dla życia jest nie tylko doraźna troska o człowieka - jakość jego egzystencji, ale również odpowiedzialne decyzje o przyszłościowym zagospodarowywaniu powierzchni ziemi - wód, przestrzeni powietrznej, obszarów należących do poszczególnych państw i tych będących dobrem wspólnym całej ludzkości. Chcąc je podejmować, należy oprócz rzetelnej wiedzy przyrodniczej posiadać także głębokie przekonanie o potrzebie zapewnienia harmonijnego współistnienia wielu form życia.

Wrażliwość na losy życia na planecie może być kształtowana od najmłodszych lat w ramach edukacji przyrodniczej, ekologicznej i zdrowotnej. Jej rozwój jest 
we współczesnych warunkach niezbędny, gdyż ustawicznie przybywa zagrożeń, z którymi coraz trudniej jest walczyć np. organizacjom ekologicznym. Obojętność, ekonomiczne priorytety, pogoń za doraźnymi korzyściami nie służą poprawie warunków bezpiecznego trwania tego, co stworzyła natura, której cząstką jest również sam człowiek.

\section{ZAKOŃCZENIE}

Treści przedmiotów przyrodniczych i techniki, realizowane na wszystkich szczeblach edukacji, stwarzają wiele doskonałych okazji do podejmowania szczególnie ważnych zadań wychowawczych z punktu widzenia nie tylko pojedynczych osób, ale społeczeństw i całej ludzkości. Hasło „wychowanie mimo wszystko” Bogdana Suchodolskiego jest nadal aktualne i dotyczy nie tylko nauczycieli reprezentujących dyscypliny - dzisiaj już niezbyt trafnie - określane mianem humanistycznych, ale także przedmiotów przyrodniczych, ścisłych, technicznych. Wiedza przyrodnicza i techniczna wykorzystywana dla dobra człowieka nabiera wartości humanistycznych i w takim aspekcie należy ją konsekwentnie przekazywać kolejnym pokoleniom, wychowując je do przyszłości - pokojowej, bezpiecznej, zdrowej - w duchu odpowiedzialności i poszanowania natury i kultury.

W aspekcie wychowawczych wyzwań, jakie stoją od lat przed edukacją przyrodniczo-techniczną, warto stawiać pytania o to, dlaczego jej efektywność i skuteczność nie są powszechnie zadowalające? Dlaczego wielu uczniów nie rozumie bądź nie jest przekonanych do konieczności uczenia się np. matematyki, fizyki, chemii, biologii? Co jest przyczyną tego, że nauczyciele tych przedmiotów, powszechnie nielubianych i uważanych za trudne, nudne i niepotrzebne w życiu, często unikają podejmowania wyzwań wychowawczych, ograniczając się do ćwiczenia jedynie umiejętności rozwiązywania testów egzaminacyjnych?

Wśród rozmaitych przyczyn jedna wydaje się zasadnicza, a mianowicie jest nią brak mechanizmów motywowania i rozliczania szkoły z działań wychowawczych. Ocenianie koncentruje się głównie na tym, jakie wiadomości i umiejętności opanowali uczniowie. Badanie i ocenianie ich postaw nastręcza spore trudności, dlatego nie jest w praktyce prowadzone. Na podstawie mechanicznego zaliczania punktów za rozwiązane zadania i udzielone w arkuszach egzaminacyjnych odpowiedzi uczniowie kwalifikowani są do grup lepszych, przeciętnych, słabszych bądź niespełniających oczekiwań. Nauczyciel obarczany jest przede wszystkim odpowiedzialnością za przygotowanie ucznia do egzaminu, za uzyskany przez niego wynik, który przesądza o dalszej karierze edukacyjnej. Wychowanie, zwłasz- 
cza na lekcjach przedmiotów przyrodniczych, nie jest priorytetem, mimo że jest możliwie i potrzebne.

W ramach ustawicznego doskonalenia programów nauczania uzasadnione jest podjęcie działań w kierunku ograniczania zakresu i szczegółowości obowiązującego materiału na rzecz eksponowania celów i działań o charakterze wychowawczym - rozwijania wrażliwości, pracowitości i odpowiedzialności uczniów za siebie, innych ludzi i środowisko przyrodnicze. Redukcja materiału nauczania powinna umożliwić zwiększenie ilości czasu na pracę metodami aktywizującymi - dyskusje, projekty, laboratoryjne eksperymenty - sprzyjającymi rozwojowi postaw i przeżywaniu wartości oraz lepszemu poznawaniu uczniów - nie tylko od strony rozwoju intelektualnego, ale również emocjonalnego i wolicjonalnego.

\section{LITERATURA}

Błasiak W., Godlewska M., Turkiewicz D. (1999). Zainteresowanie uczniów fizykq - wyniki badań porównawczych. „Problemy Studiów Nauczycielskich” 20.

Błażejewski W. (2011). Skuteczność strukturalnego kształcenia przyrodniczo-technicznego. Wydawnictwo PWSTE w Jarosławiu, Jarosław.

Błażejewski W. (2013). Kanon, skuteczność i efektywność kształcenia ogólnego w Polsce. Wydawnictwo Uniwersytetu Rzeszowskiego, Rzeszów.

Frumanek W. (red.) (2008). Wartości w pedagogice. Czas jako wartość we współczesnej pedagogice. Wydawnictwo FOSZE, Rzeszów.

Furmanek W. (red.) (1995). Modelowanie treści kształcenia ogólnotechnicznego dla potrzeb nowego systemu oświaty. Wydawnictwo WSP, Rzeszów.

Heller M. (1998). Czy fizyka jest nauka humanistyczna? Wydawnictwo Diecezji Tarnowskiej BIBLOS, Tarnów.

Herbst M., Herczyński J., Levitas A. (2009). Finansowanie oświaty w Polsce - diagnoza, dylematy, możliwości. Warszawa.

Krogulecka K. (tłum.) (1994). Europejski Program Badań Zanieczyszczeń Powietrza (Air Pollution Project Europe), Wydane przez Norweskie Towarzystwo Ochrony Przyrody.

Łysiak W. (2000). Stulecie kłamców. Wydawnictwo Andrzej Frukacz, Ex Libris - Galeria Polskiej Książki, Chicago-Warszawa.

Nowacki T.W. (1999). O metodzie projektów. Z. 47. Wydawnictwo CODN Pracownia Edukacji Zawodowej, Warszawa.

Suchodolski B. (1990). Wychowanie mimo wszystko. Wydawnictwo PWN, Warszawa. 
Wciórka B. (oprac.) (2009). Aspiracje i motywacje edukacyjne Polaków w latach 1993-2009. CBOS, Komunikat z badań BS/70/2009, Warszawa.

\title{
EDUCATION IN NATURAL SCIENCE AND TECHNOLOGY CLASSES
}

\begin{abstract}
The aspect of nature has always been present in the general education canon. It has served as a tool for describing the Universe as well as the role and place of man - to satisfy the natural curiosity. Nowadays, natural and technical science are not only designed for giving pupils basic knowledge but also for educational purposes - developing certain attitude, internalizing values, interests, responsibility, and character traits. Only the selection of teaching methods, which enable pupils to actively engage in solving essential problems, undertake individual initiatives and studies, learn the value of work, and appreciate scientific achievements, can make their educational values fully revealed, understood and utilized. Getting to know the history of natural science and technology, and scientists' and inventors' biographies should cause deeper reflection on one's role in multiplying and improving historical achievements of culture and civilization, and the importance of devotion, passion and persistence in achieving one's purpose.
\end{abstract}

Key words: teaching biology and technology, project method, values, education 